\title{
Starost otrok ob vstopu v šolo in učni dosežki pri matematiki v prvem razredu
}

\author{
Marina Volk \\ Univerza na Primorskem \\ marina.volk@pef.upr.si \\ Mojca Vidic \\ Univerza na Primorskem \\ mojca.vidic@osgradec.si
}

\begin{abstract}
V Sloveniji tako kot v večini evropskih držav otroci v šolo vstopijo pri šestih letih, vendar imajo starši možnost zaprositi za odlog všolanja za eno šolsko leto. $\checkmark$ zadnjih letih beležimo vse večji odstotek odloga vpisa v prvi razred tudi zaradi prepričanja, da bodo starejši učenci lažje sledili pouku in bodo tako učno uspešnejši. $V$ prispevku smo se osredotočili na uspešnost pri reševanju matematičnega preizkusa znanja glede na različno starost otrok $v$ prvem razredu in hkrati preverili tudi, ali se pojavljajo razlike v uspešnosti med dečki in deklicami. Učenci se $z$ matematiko prvič ne srečajo ob vstopu v šolo, saj so matematično mišljenje postopoma gradili od rojstva naprej. Pomemben vpliv na uspeh pri matematiki ima tudi zgodnje učenje matematike v predšolskem obdobju, ki postavi trdne temelje za nadgrajevanje znanja pri nadaljnjem šolanju. $\mathrm{Na}$ podlagi naše raziskave smo ugotovili, da so bili tako starejši kot mlajši učenci prvega razreda zelo izenačeni v znanju pri matematičnem preizkusu znanja; prav tako se ni pokazala razlika $v$ znanju med dečki in deklicami.
\end{abstract}

Ključne besede: učna uspešnost pri matematiki, starost, spol

\section{Teoretični uvod}

Človek se rodi z zmožnostjo sporazumevanja; otrok se v prvem letu nauči sporazumevati v primarnem jeziku brez posebnih usmeritev in z občutkom za števila, kar pomeni, da je malček zmožen določiti moč manjše množice, šteti in izvesti preprosto dodajanje (seštevanje) ter odvzemanje (odštevanje) brez predhodnega učenja (Bergant 2014a; Sousa 2015), kar teoretično pomeni, da imamo vsi enako izhodišče glede učenja matematike. Predšolski otroci se spontano ali s posnemanjem vrstnikov učijo reševati enostavne aritmetične probleme (Sousa 2015), vendar pa je naloga vzgojitelja/odraslega, da otrokom ponudi možnost raziskovanja in pridobivanja matematičnih konceptov, saj intuitivno znanje matematike, ki je obogateno z izkušnjami iz predšolskega obdobja, določa tudi zmožnost nadgrajevanja matematičnega 
znanja pri nadaljnjem šolanju (Bergant 2014a). Učenje števil in njihovo povezovanje s predmeti ter razvoj količinskih predstav in drugih matematičnih veščin, prilagojenih potrebam in razvoju posameznika, $v$ predšolskem obdobju pozitivno vplivajo na uspešno razumevanje matematičnih učnih vsebin $v$ obdobju šolanja, saj se je matematično predznanje izgrajevalo postopoma (Cross in Woods 2009; Bergant 2012). Japelj Pavešićeva (2014) povzame podatke iz raziskave TIMSS 2011, ${ }^{1}$ ki kažejo na pomemben vpliv zgodnjega učenja matematike na kasnejšo uspešnost pri matematiki; $v$ vseh kategorijah je bilo namreč znanje otrok, ki so ob vstopu v prvi razred znali več matematike, višje tudi v četrtem razredu. Avtorica opozori, da ni mogoče potrditi neposredne vzročne zveze med znanjem pred šolo in v šoli, saj na razvoj znanja otroka med vstopom $v$ prvi razred in četrtim razredom vpliva še veliko zunanjih dejavnikov, ki jih v raziskavi niso obravnavali. V Kurikulumu za vrtce (Ministrstvo za šolstvo in šport 1999) niso predpisani standardi znanja, ki jih morajo doseči otroci, vključeni v vrtec. Iz podatkov raziskave TIMSS 2011 lahko sklepamo, da velika večina otrok osnovne elemente matematike usvoji že pred vstopom v šolo. Matematične vsebine so otrokom v vrtcu predstavljene v povezavi z drugimi področji in skozi igro, ki jim je najbližja. Otroci v predšolskem obdobju prve izkušnje z matematiko pridobivajo tako, da postopoma preidejo od poimenovanja posamičnih predmetov na štetje in razlikovanje med številom ter števnikom, razvrščajo, urejajo, dodajajo/odvzemajo, merijo itd. (Ministrstvo za šolstvo in šport 1999). Z vstopom v prvi razred pridobljeno znanje dopolnijo in nadgradijo. Povzamemo lahko, da ima zgodnje poučevanje matematike velik pomen za kasnejše grajenje matematičnega znanja.

Matematika ima kot šolski predmet številne izobraževalno-informativne, funkcionalno-formativne in vzgojne funkcije. Pri pouku matematike obravnavamo temeljne in pomembne matematične pojme, ki so usklajeni z učenčevim kognitivnim razvojem, s sposobnostmi, z osebnostnimi značilnostmi in njegovim življenjskim okoljem (Ministrstvo za šolstvo in šport 2011). Matematika in matematične spretnosti se vedno bolj dojemajo kot podlaga za učenje drugih šolskih predmetov (Kresal Sterniša in Plevnik 2012), zato je priporočljivo, da učitelji matematična znanja in spretnosti vključujejo v medpredmetno poučevanje, saj s tem učenci začutijo pomen in prisotnost matematike vse okrog nas. Po podatkih raziskave Eurydice se je po posodobitvah kurikulumov $v$ večini evropskih držav izboljšala povezava med matematič-

\footnotetext{
${ }^{1} \mathrm{~V}$ raziskavo TIMSS 2011 je bilo prvič dodano zbiranje informacij o priložnostih za zgodnje učenje, ki jih je bil deležen otrok, in o njegovem znanju ob vstopu v šolo s pomočjo dodatnega vprašalnika za starše (Japelj Pavešić 2014).
} 
nim znanjem, pridobljenim $v$ šoli, in osebnimi izkušnjami učencev ter težavami iz vsakdanjega življenja (Kresal Sterniša in Plevnik 2012). Priporočen čas pouka matematike na razredni stopnji je navadno med 15 in 20 odstotki vseh ur, kar pomeni, da je matematika drugi najpomembnejši predmet, takoj za učnim jezikom. Način poučevanja in metode, ki se uporabljajo pri pouku matematike, lahko močno vplivajo na kakovost in količino znanja, ki ga učenci usvojijo. Poleg tega izbrane metode vplivajo tudi na sodelovanje učencev in na njihovo veselje ob učenju, kar spet neposredno vpliva na količino in kakovost njihovega znanja (Kresal Sterniša in Plevnik 2012). Z učenjem matematike otroci odkrivajo matematiko, ob njej razmišljajo in skozi to nadgrajujejo svoje znanje. Učenje matematike poteka z reševanjem problemov, ${ }^{2}$ zato tudi osnovne matematične pojme otroci spoznavajo s pomočjo problemskih situacij, katerih problem izhaja iz njihovih lastnih in dejanskih spoznavnih potreb (Cotič in Felda 2014). Pri oblikovanju matematičnih pojmov in procesov je bistveno pridobivanje izkušenj in uvrščanje novih izkušenj v obstoječo shemo. Matematični procesi so znanja, ki niso ozko predmetnospecifična in so zato visoko prenosljiva (Lipovec in Antolin Drešar 2019). Pomembno je, da imajo učenci že na razredni stopnji pozitivne izkušnje $z$ matematiko ter da dosegajo določene standarde znanja, saj to vpliva na njihov napredek pri matematiki in ostalih predmetih na predmetni stopnji ter pri nadaljnjem šolanju; v nasprotnem primeru zapustijo osnovno šolo, ne da bi zanesljivo razumeli osnovne matematične koncepte (Burr 2008). V današnjem hitro spreminjajočem se svetu bodo imeli prednost pri oblikovanju prihodnosti tisti, ki razumejo matematiko; matematične kompetence odpirajo vrata k ustvarjanju prihodnosti, medtem ko pomanjkanje teh kompetenc pusti vrata priprta. Vsi učenci bi morali imeti priložnost in podporo pri učenju matematike z razumevanjem in pri doživljanju lepote matematike (National Council of Teachers of Mathematics 2000), ne glede na starost, spol, socialni status, predznanje ...

Pri poučevanju na razredni stopnji stremimo k razvijanju intuicije, domišljije, kreativnosti, sklepanja, načrtovanja in preverjanja domnev itd., saj $s$ tem razvijamo otrokovo mišljenje (Felda in Cotič 2012). Glede na to, da je večina učencev ob vstopu $v$ šolo na ravni konkretnih miselnih operacij, je pomembno, da jim omogočimo delo s konkretnim materialom, preko katerega preizkušajo svoje matematične predpostavke (npr. o odnosih med števili ipd.) in se matematike učijo skozi vidik lastnih napak in ugotovitev. Ma-

\footnotetext{
${ }^{2}$ Učenje matematike s pomočjo reševanja problemov je pomembno, saj je človek različne teorije razvil ravno $v$ situacijah, ko je bilo potrebno rešiti problem, vendar mu znani načini in sredstva za reševanje le-tega niso več zadoščali (Cotič in Felda 2014).
} 
tematične miselne sheme in pojmi se utrdijo prav s pomočjo manipulacije $s$ konkretnimi objekti (Vlahović-Štetić in Vizek Vidović 1998). Vzporedno s konkretno ravnjo matematiko prikazujemo tudi preko slikovne ravni, da bo otrok kasneje lahko prešel na simbolno raven. Ko opazimo, da učenci ne potrebujejo več toliko manipulacije $s$ konkretnimi materiali, lahko konkretno raven opustimo in problem ali matematično vsebino prikažemo na slikovni in kasneje na simbolni ravni. Učenci v prvem razredu spoznavajo različne matematične vsebine, ki se večinoma povezujejo $z$ matematičnimi vsebinami, ki so jih otroci spoznali že $v$ vrtcu. $V$ prvem razredu učenci spoznajo in nadgradijo pojme iz orientacije, s pomočjo konkretnih predmetov spoznajo geometrijske elemente po konceptu »od telesa k točki«, vadijo ocenjevanje in merjenje $z$ relativno in nestandardno enoto, gradijo konceptualni sistem za reprezentacijo številskih predstav ${ }^{3}$ ter se seznanijo $z$ računsko operacijo seštevanja in odštevanja. Pri sklopu »Logika in jezik« se učenci navajajo na pravilno in natančno (matematično) izražanje preko opisovanja lastnosti elementov množic ter hkrati razvijajo bralno pismenost (Ministrstvo za šolstvo in šport 2011). Seznanijo se tudi z obdelavo podatkov ter se učijo iskanja potrebnih podatkov iz preglednic in prikazov. V prvem vzgojno-izobraževalnem obdobju je obdelava podatkov učinkovit način razvijanja količinskega razumevanja in sklepanja ter uporabe aritmetike pri reševanju problemov (Žakelj 2013). Učenci se seznanijo tudi z vzorci, ki so predvsem geometrijski in slikovni. S samostojnim oblikovanjem vzorcev razvijajo kreativnost in sprejemajo matematiko kot način mišljenja. Žakljeva (2013) poudari, da naj učenci rešujejo matematične probleme pri vseh vsebinskih sklopih. Skoznje utrjujejo osnovna znanja, učno vsebino povezujejo z življenjskimi situacijami ter se učijo strategij za reševanje problemov (Žakelj 2013). Že v prvem razredu sta pomembna prepoznavanje težav pri matematiki in ustrezna pomoč, ki preprečita, da bi se učenci naučili neprimernih strategij in razvili napačne predstave, ki bi lahko prerasle $v$ dolgoročne ovire pri učenju matematike.

Prestop otrok iz vrtca v prvi razred je zelo pomembno obdobje. Za otroka predstavlja tranzicijo iz domačega okolja ali vrtca v okolje, kjer so kompleksnejše interakcije in kjer prevladujejo formalnejše medosebne vezi (»Rethinking School Readiness" 2008). V Sloveniji so do uvedbe devetletne osnovne šole otroci vstopili v šolo, ko so dopolnili sedem let. Od leta 2003, ko je stopila v veljavo devetletna osnovna šola, pa so $k$ vpisu v prvi razred povabljeni otroci, »ki bodo $v$ koledarskem letu, $v$ katerem bodo začeli obiskovati šolo,

\footnotetext{
${ }^{3} \mathrm{~V}$ prvem razredu učenci najprej spoznajo števila do 10 in nato še do 20 ter števila seštevajo in odštevajo.
} 
dopolnili starost 6 let (45. člen Zakona o Osnovni šoli 2006). Zgodnejši vstop $v$ šolo otrokom iz intelektualno manj spodbudnih okolij omogoča intelektualno spodbudnejše okolje in tako prispeva k zmanjševanju razlik med učenci (Cecić Erpič 1999). Čeprav se otroci med seboj precej razlikujejo, jih večina pri šestih letih doseže razvojne mejnike, ki omogočajo redno všolanje (Bergant 2014b). Zakon o Osnovni šoli (1996, 45. člen) dopušča možnost, da se »otroku začetek šolanja na predlog staršev, zdravstvene službe oz. na podlagi odločbe o usmeritvi odloži za eno leto, če se ugotovi, da otrok ni pripravljen za vstop v šolo«. Iz objav Ministrstva za šolstvo in šport v javnih medijih v Sloveniji beležimo povečanje deleža otrok z odloženim šolanjem; $v$ šolskem letu 2011/2012 je pet \% učencev začelo obiskovati prvi razred eno leto kasneje; v šolskem letu 2019/2020 je bilo takšnih učencev že približno $12 \%$. Razlogi za odložitev šolanja so različni (posebne potrebe otrok, fizična, čustvena ali socialna nezrelost ipd.).

Nekateri učenci med izobraževanjem uživajo ekonomsko, čustveno in socialno oporo, medtem ko drugi živijo v okolju, ki jim tega ne omogoča. Rezultati preteklih ciklov raziskave PISA kažejo, da učenci, ki poročajo, da izhajajo iz socialno-ekonomsko šibkejših okolij, poročajo tudi o tem, da so njihovi starši dosegli nižje stopnje izobrazbe in v povprečju dosegajo nižje rezultate na preizkusih PISA (Šterman Ivančič 2019). Zupančičeva in Puklekova (1999) sta s študijo o spremenljivkah, ki vplivajo na otrokovo učno uspešnost, pokazali, da je povezanost med izobrazbo staršev in otrokovo uspešnostjo zmerno visoka oz. najvišja izmed vseh povezav, ki sta jih ugotavljali z raziskavo, medtem ko spol in kronološka starost ob vstopu v šolo ne nakazujeta na uspeh otroka v prvem razredu. Marjanovič Umekova, Fekonjeva in Bajčeva (2006) so $z$ raziskavo dokazale pozitiven učinek vključevanja $v$ vrtec na pripravljenost otrok staršev z nizko izobrazbo za šolo (pri otrocih staršev z visoko izobrazbo se ta učinek ${ }^{4}$ ni pokazal v tolikšni meri). Zupančičeva in Puklekova (1999) sta ugotovili, da otrokovi sposobnosti sklepanja in dojemanja količinskih odnosov, ${ }^{5}$ ki sta ju merili pred vstopom v šolo, nimata neposrednega vpliva na učno uspešnost $v$ prvem razredu, temveč sta posredno povezani $z$ izobrazbo otrokovih staršev.

Pri merjenju vpliva starosti na učni uspeh v prvem razredu ali pri nadaljnjem šolanju lahko raziskujemo (I.) prednosti otrok, ki so $v$ šolo zaradi odlo-

${ }^{4}$ Otroci, ki prihajajo iz socialno-ekonomsko spodbudnega okolja, so praviloma kakovostnih spodbud deležni že v domačem okolju in le-teh vrtec ne preseže (Marjanovič Umek, Fekonja in Bajc 2006).

${ }^{5}$ Sposobnost sklepanja, dojemanja količinskih odnosov ter grafomotorične spretnosti so merili s podtesti POŠ (Preizkus pripravljenosti otrok na šolo). 
žitve šolanja vstopili $z$ enoletnim zamikom $v$ primerjavi $z$ ostalimi učenci $v$ skupini, ali pa (II.) vpliv kronološke starosti otrok, rojenih v istem letu, med katerimi je lahko razlika v starosti do 12 mesecev (Stipek 2003). Cahan in Cohenova sta izvedla eksperiment, s katerim sta dokazala, da ima leto šolanja dvakrat tolikšen učinek na kognitivni napredek, kot ga ima zamik všolanja za eno leto (Cahan in Cohen 1989). Šolanju je na področju matematike mogoče pripisati predvsem napredek pri razvoju logično-matematičnih veščin, medtem ko je vpliv šolanja na razumevanje ohranitve količin (npr. mase, tekočine ...) zelo majhen in je posledica otrokovih razvojnega zorenja in zunajšolskih izkušenj (Cahan idr. 2008). Stipekova (2003) je na podlagi različnih raziskav, ki so merile vpliv kronološke starosti ob vstopu v prvi razred na učni uspeh, povzela, da starost v nekaterih primerih vpliva na učno uspešnost starejših učencev $v$ začetnem obdobju šolanja, vendar pa mlajši učenci kmalu dohitijo starejše in tako prednost slednjih izzveni (lahko še pred zaključkom prvega razreda). Tudi novejša raziskava, ki so jo opravili v Avstraliji in je merila vpliv odloženega vpisa v prvi razred na uspeh pri branju in računanju, potrjuje že prej zapisano, in sicer da starejši učenci boljše uspehe pri branju in računanju dosegajo le nekaj časa. So pa v isti študiji ugotovili, da so starejši učenci lahko dlje časa osredotočeni na zadane naloge in so kazali manj hiperaktivnosti (Larsen, Little in Coventry 2021). Na kognitivni napredek posameznega učenca vpliva veliko dejavnikov, od vključenosti v vrtec, družine in okolja, osebnostnih značilnosti, otrokovih sposobnosti do počutja $v$ šoli ipd., ki se medsebojno prepletajo in sovplivajo na razvoj.

\section{Namen raziskave in raziskovalna vprašanja}

Glede na porast števila odlogov všolanja v prvi razred v Sloveniji v zadnjih desetih letih smo se odločili raziskati, ali lahko na podlagi starosti prvošolcev napovemo učno uspešnost na matematičnem področju. Namen raziskave je bil ugotoviti, ali obstajajo razlike $v$ uspešnosti pri matematiki med različno starimi učenci prvega razreda glede na to, da je med učenci v prvem razredu razlika v kronološki starosti tudi 12 mesecev. Prav tako smo v okviru empirične raziskave želeli ugotoviti, ali se starost učencev prvega razreda povezuje z uspešnostjo na posameznih matematičnih področjih. Zanimalo nas je tudi, ali se pri učencih prvega razreda v uspešnosti pri matematiki pojavljajo razlike med spoloma.

Pred izvedbo raziskave smo se spraševali naslednje:

- ali v uspešnosti pri matematiki obstajajo razlike med različno starimi učenci prvega razreda, 
Preglednica 1

Število udeležencev glede na spol in starost

\begin{tabular}{lrrr}
\hline Spol & \multicolumn{3}{c}{ Starost } \\
\cline { 2 - 4 } & Starejši & Mlajši & Skupaj \\
\hline Ženski & 35 & 31 & 66 \\
Moški & 36 & 29 & 65 \\
Skupaj & 71 & 60 & 131 \\
\hline
\end{tabular}

- ali v uspešnosti na posameznih matematičnih področjih obstajajo razlike med različno starimi učenci prvega razreda,

- ali se pri reševanju matematičnih nalog pojavljajo razlike med deklicami in dečki.

\section{Metodologija}

\section{Raziskovalni vzorec}

Raziskava temelji na neslučajnostnem, namensko izbranem vzorcu. V vzorec je bilo vključeno 131 učencev prvega razreda osnovnih šol v savinjski regiji, od tega 66 učenk in 65 učencev. V skupino starejših učencev so bili uvrščeni učenci, rojeni med januarjem in junijem (71 učencev), v skupino mlajših učencev pa učenci, rojeni med julijem in decembrom (60 učencev) (preglednica 1), kar pomeni, da so bili učenci stari od pet let in osem mesecev do šest let in osem mesecev. $V$ raziskovalnem vzorcu ni bilo nobenega učenca, ki bi zaradi kasnejšega všolanja v prvi razred vstopil s sedmimi leti.

\section{Merski pripomoček in potek raziskave}

Podatke smo zbirali s pomočjo preizkusa znanja, ki je temeljil na matematičnih vsebinah prvega razreda. Preizkus znanja je bil sestavljen iz 12 nalog, ki so vključevale matematične vsebine aritmetike, geometrije, obdelave podatkov in logike. Preizkus so pred izvedbo testiranja pregledali učitelji, ki so učence poučevali, in potrdili, da so predhodno z učenci obravnavali vse matematične vsebine, zaobsežene $v$ preizkusu. Večina nalog je imela tudi slikovno gradivo za lažjo predstavo učencev. Naloge v preizkusu znanja so bile zastavljene po Gagnejevi taksonomiji. Indeks težavnosti ${ }^{6}$ nalog v preizkusu znanja je v povprečju znašal o,79 oz. je bila večina nalog v območju od o,60 do o,90. Najzahtevnejši sta bili 11. in 12. naloga; njuna indeksa težavnosti sta bila 0,53 in 0,36 , kar je pričakovano, saj sta bili uvrščeni v najvišjo taksonomsko raven.

Starši učencev, vključenih v raziskavo, so bili obveščeni o namenu raziskave in so s podpisom podali soglasje o tem, da lahko njihov otrok sodeluje

\footnotetext{
${ }^{6}$ Vrednosti blizu 1 kažejo na manj zahtevno nalogo oz. nalogo, ki so jo skoraj vsi rešili pravilno, vrednosti blizu o pa zahtevno nalogo, pri kateri le malo učencev doseže najvišje število točk.
} 
Preglednica 2 Opisna statistika preizkusa znanja za vse učence skupaj

\begin{tabular}{lrrrrrrrrrrrr}
\hline Postavka & \multicolumn{10}{c}{ Vprašanje } \\
\cline { 2 - 13 } & 1 & 2 & 3 & 4 & 5 & 6 & 7 & 8 & 9 & 10 & 11 & 12 \\
\hline$N$ & 131 & 131 & 131 & 131 & 131 & 131 & 131 & 131 & 131 & 131 & 131 & 131 \\
$M$ & 4,24 & 3,95 & 1,79 & 5,15 & 6,50 & 0,87 & 3,18 & 8,60 & 11,25 & 0,61 & 2,15 & 0,36 \\
$S D$ & 1,42 & 0,26 & 0,49 & 1,52 & 1,17 & 0,34 & 1,03 & 1,59 & 1,71 & 0,50 & 1,68 & 0,48 \\
$S E$ & 0,12 & 0,02 & 0,04 & 0,13 & 0,10 & 0,03 & 0,09 & 0,14 & 0,15 & 0,04 & 0,15 & 0,04 \\
Min & 0,00 & 2,00 & 0,00 & 0,00 & 0,00 & 0,00 & 0,00 & 0,00 & 0,00 & 0,00 & 0,00 & 0,00 \\
Max & 5,00 & 4,00 & 2,00 & 6,00 & 7,00 & 1,00 & 4,00 & 9,00 & 12,00 & 1,00 & 4,00 & 1,00 \\
\hline
\end{tabular}

pri preizkusu znanja, pri čemer smo jim zagotovili anonimnost pridobljenih podatkov. Učenci so preizkuse znanja reševali eno šolsko uro v času rednega pouka ob prisotnosti učitelja razrednika in testatorja. Učitelj je navodila nalog prebral, saj v času izvajanja preizkusa znanja v branju in razumevanju prebranega še niso bili spretni vsi učenci.

\section{Postopek obdelave podatkov}

Podatke, pridobljene s preizkusom znanja, smo na podlagi zastavljenih kriterijev ocenili in vnesli v računalniški program IBM SPSS Statistic 26.0 ter jih ustrezno obdelali. Uporabljeni so bili deskriptivna statistika in ustrezni testi za ugotavljanje razlik v uspešnosti reševanja matematičnih nalog med različno starimi učenci ter glede na spol ( $t$-test).

\section{Rezultati in interpretacija}

V nadaljevanju so predstavljeni dosežki učencev prvega razreda pri reševanju preizkusa znanja glede na raziskovalne cilje, ki smo si jih zastavili.

$\checkmark$ preglednici 2 je prikazana opisna statistika posamezne naloge preizkusa znanja skupaj za vse učence, ki so reševali test. Učenci so najuspešneje reševali 2. nalogo, ${ }^{7}$ saj so v povprečju dosegli 3,95 od 4 točk, najmanj uspešno pa 12. nalogo, ${ }^{8}$ kjer so v povprečju dosegli o,36 od 1 možne točke (indeks težavnosti te naloge je najnižji med vsemi, IT =0,36).

\section{Analiza razlik v uspešnosti reševanja preizkusa znanja glede na starost učencev $v 1$. razredu}

S preizkusom znanja smo preverjali, ali so med starejšimi in mlajšimi učenci prvega razreda razlike $v$ znanju matematike, ki obsega matematične učne

${ }^{7}$ Učenci so morali pri 2. nalogi prepoznati osnovne geometrijske like in jih pobarvati po navodilih.

${ }^{8}$ Zadnja naloga preizkusa znanja je bila besedilna naloga, pri kateri so morali učenci seštevati. 
Preglednica 3

Uspešnost reševanja matematičnega testa glede na starost otrok

\begin{tabular}{lrr}
\hline Postavka & $\begin{array}{r}\text { Starejši učenci } \\
\text { (januar-junij) }\end{array}$ & $\begin{array}{r}\text { Mlajši učenci } \\
\text { (julij-december) }\end{array}$ \\
\hline$N$ & 71 & 60 \\
$M$ & 48,58 & 48,35 \\
$S D$ & 5,145 & 6,345 \\
\hline
\end{tabular}

vsebine prvega razreda. $V$ preglednici 3 vidimo, kako uspešno so preizkus znanja reševali starejši in mlajši učenci prvega razreda. Najvišje število točk, ki so ga učenci lahko dosegli, je bilo 56 . Starejši učenci so v povprečju dosegli 48,58, mlajši pa 48,35 točk, kar pomeni, da so razlike med otroci starejše in mlajše skupine minimalne, zato $t$-preizkus ni zaznal statistično pomembnih razlik v uspešnosti reševanja preizkusa znanja med starejšimi in mlajšimi učenci prvega razreda $(2 p=0,821>0,05 ; t=0,227)$. Zaključimo lahko, da $v$ našem raziskovalnem vzorcu starost ob vpisu v prvi razred ni vplivala na uspešnost pri reševanju preizkusa znanja iz matematike, saj se je izkazalo, da so tako mlajši kot starejši učenci $v$ znanju izenačeni in obe skupini otrok sta zelo uspešno reševali naloge, ki vključujejo vsebine iz matematike $v$ prvem razredu. Nekatere raziskave so pri branju in matematiki nekje do tretjega oz. petega razreda potrdile višji učni uspeh starejših otrok v skupini v primerjavi z mlajšimi (Oshima in Domaleski 2006), medtem ko večina raziskav kaže na to, da se razlika $v$ učni uspešnosti zaradi različnih starosti izenači že do konca prvega razreda (Stipek 2003; Larsen, Little in Coventry 2021).

Nadalje smo pogledali, ali se $v$ uspešnosti reševanja posameznih nalog $v$ preizkusu znanja kažejo razlike med starejšimi in mlajšimi učenci. Pri večini nalog so bili starejši učenci v povprečju nekoliko uspešnejši od mlajših, vendar te razlike niso bile statistično pomembne, razen pri 3. nalogi, ki je zahtevala urejanje elementov. Pri tej so se pokazale statistično pomembne razlike $v$ prid starejših učencev $(2 P=0,010<0,05 ; t=2,648)$. Mlajši učenci so bili uspešnejši pri reševanju naloge, ki je preverjala znanje seštevanja in odštevanja do 10, vendar razlika med skupinama ni statistično pomembna; omenjeno nalogo je v celoti pravilno rešilo $60 \%$ starejših in $70 \%$ mlajših otrok, kar pomeni, da so učenci prvega razreda zelo spretni pri računanju (naloga ni bila slikovno podprta). Na podlagi dobljenih rezultatov preizkusa znanja ne moremo trditi, da so na posameznem matematičnem področju starejši učenci v prednosti pred mlajšimi, saj se je izkazalo, da sta obe skupini zelo izenačeni $v$ znanju na vseh matematičnih področjih. Zaključimo lahko z ugotovitvijo Gabra in Marjanovič Umekove (2009), da kronološka starost otroka, pri kateri ta vstopi v prvi razred, ne kaže nobene pomembne vzporednice $z$ njegovo 
učno uspešnostjo ali govorno kompetentnostjo, intelektualnimi sposobnosti in navsezadnje s pripravljenostjo za šolo.

Razloge za uspešno reševanje preizkusa znanja je težko enoznačno določiti, saj poleg učiteljevega poučevanja matematike $v$ šoli na uspeh pri predmetu vplivajo tudi otrokovo družinsko okolje, njegove osebnostne značilnosti in vključenost $v$ vrtec pred vstopom $v$ šolo. Po podatkih Statističnega urada Republike Slovenije je bilo v šolskem letu 2019/2020 v vrtce vključenih približno $94 \%$ otrok, starih štiri in pet let. Evropski strateški cilj je predvideval, da naj bi bilo do leta 2020 v predšolsko izobraževanje vključenih $95 \%$ štiriin petletnih otrok (Kozmelj 2020), kar pomeni, da je Slovenija že zelo blizu postavljenemu cilju. $V$ Sloveniji ne zbiramo uradnih podatkov o tem, katera znanja, spretnosti in kompetence imajo otroci ob vstopu $v$ šolo, saj otrok na nacionalni ravni ne preverjamo (Japelj Pavešić 2014), tako da ne moremo zagotovo trditi, da je večina učencev imela določena matematična znanja, ki jih je v prvem razredu obnovila ali nadgradila. Marjanovič Umekova, Fekonjeva in Bajčeva so ugotovile $(2006,41)$, da ima vključenost otrok v vrtec učinek na otrokovo pripravljenost za šolo le $v$ interakciji z izobrazbo mame in očeta preizkusi kažejo, da »v skupini otrok, ki do vstopa v šolo niso bili vključeni $v$ vrtec, dosegajo statistično pomembno nižje rezultate na preizkusu pripravljenosti za šolo otroci mam in očetov z nizko stopnjo izobrazbe kot otroci mam in očetov $z$ visoko stopno izobrazbe«.

\section{Analiza razlik v uspešnosti reševanja preizkusa znanja glede na spol učencev $v$ prvem razredu}

V raziskavi TIMSS 2011 se je pri učencih 4. razreda pokazalo, da so deklice $v$ Sloveniji »v povprečju dosegle več točk na preizkusih znanja iz bralne pismenosti; obenem je večji delež deklic kot fantov izkazal visoko znanje branja. Ti pa so bili prvič, odkar neodvisno merimo znanje matematike, boljši od deklic $v$ matematiki. $V$ povprečju so dosegli 10 točk več na preizkusu znanja matematike in $v$ večjem deležu od deklic demonstrirali visoko znanje matematike v četrtem razredu.« (Japelj Pavešić 2014, 22) Raziskava je razkrila še zanimive podatke o razlikah $v$ aktivnostih, ki jih starši počnejo s svojimi predšolskimi otroki - starši deklic so poročali o pogostejših bralnih aktivnostih, starši dečkov pa o pogostejših matematično orientiranih dejavnostih (Japelj Pavešić 2014), kar pomeni, da je uspeh pri matematiki lahko pogojen tudi z zgodnjim vključevanjem oz. izključevanjem otrok pri matematičnih aktivnostih.

Tudi mi smo želeli s preizkusom znanja ugotoviti, ali se med dečki in deklicami v prvem razredu pojavljajo razlike $v$ uspešnosti reševanja matematičnih nalog. Podatke smo analizirali za vse deklice in vse dečke skupaj; nismo 
jih ločili glede na starost. Dečki so na preizkusu znanja v povprečju dosegli 48 točk, deklice pa 49 točk, kar pomeni, da se razlikujejo v povprečju za eno točko. Razlike med spoloma na našem vzorcu niso statistično pomembne ( $2 p$ $=0,450>0,05 ; t=0,757)$. Oshima in Domaleski (2006) sta ugotovila, da je vpliv spola na uspešnost pri matematiki v nižjih razredih zelo majhen, medtem ko $v$ višjih razredih malo naraste $v$ prid uspešnosti dečkov. Raziskava TIMSS ni ugotovila razlik med spoloma, ki bi jih lahko posplošili na celotno populacijo, medtem ko je raziskava PISA v vseh krogih meritev poročala o rahli prednosti fantov, vendar ne v vseh državah. Izsledki raziskave PISA kažejo tudi na to, da so fantje veliko samozavestnejši pri reševanju matematičnih nalog; zanimajo se za matematiko in uživajo $v$ njej, medtem ko se pri dekletih kaže obraten trend (Kresal Sterniša in Plevnik 2012). Veliko vlogo pri odpravljanju razlik med spoloma imajo v prvi vrsti vzgojitelji v vrtcu, ki premišljeno uvajajo skupinske matematične dejavnosti, da pritegnejo vse otroke. Ob tem se zmanjša zaostanek tistih otrok, ki doma nimajo dovolj spodbud za razvoj matematičnega mišljenja (Japelj Pavešić 2014). Učitelji v osnovni šoli bi morali dati večji poudarek razvoju pozitivnega odnosa deklet do matematike, saj bi tako zvišali njihovo samozavest in posledično uspešnost na matematičnem področju.

\section{Zaključek}

Pomembni cilji poučevanja matematike v osnovni šoli so predvsem demonstracija uporabnosti in funkcionalnosti matematike, razvijanje prenosljivih spretnosti, epistemološki cilji, ki se nanašajo na različne metode spoznavanja pri matematiki, ter doživljanje »lepote matematike« (Haylock in Thangata 2007). Ob tem je pomembno, da učitelj z učenci v začetnem obdobju šolanja gradi pozitiven odnos do predmeta ter dobro počutje ob učenju, saj to vpliva na učenčev napredek pri matematiki in ostalih predmetih na predmetni stopnji ter pri nadaljnjem šolanju. Na učenčevo uspešnost pri matematiki pa ne vpliva le učitelj, temveč še vrsta drugih dejavnikov, na katere učitelj nima neposrednega vpliva, npr. izobrazbena struktura staršev in socialno okolje, v katerem otrok odrašča, vključenost v vrtec pred vstopom v šolo, zrelost otroka ob vstopu v prvi razred ipd.

$Z$ našo raziskavo smo želeli preveriti, ali sta starost in spol učencev prvega razreda pomembna dejavnika uspešnosti pri matematiki. Znanje matematike učencev prvega razreda smo ocenili na podlagi preizkusa znanja, ki ga je rešilo 131 prvošolcev, ki so bili razdeljeni v dve starostni skupini glede na mesec rojstva. Ugotovili smo, da med starejšimi in mlajšimi učenci prvega razreda ni statistično pomembnih razlik v znanju matematike. Prav tako se med obema skupinama ne pojavljajo razlike $v$ znanju na posameznih matematič- 
nih področjih. Sklenemo lahko, da starost ob vstopu v prvi razred ne vpliva na uspeh pri matematiki, vendar teh ugotovitev ne moremo posplošiti na celotno populacijo zaradi premajhnega števila testiranih učencev. Raziskovalci tega področja (Stipek 2003; Larsen, Little in Coventry 2021) ugotavljajo, da imajo otroci, ki so $v$ razredu starejši od sošolcev, določeno prednost, ki pa se z leti zmanjšuje oz. izniči. Raziskave, ki so pokazale razlike $v$ starosti otrok in njihovi uspešnosti $v$ šoli, kažejo na to, da so te razlike opazne na začetku šolanja, vendar pa mlajši otroci hitro dohitijo starejše vrstnike.

$\mathrm{Ob}$ analizi podatkov preizkusa matematičnega znanja na našem vzorcu smo ugotovili, da $v$ prvem razredu $v$ znanju matematike ni statistično pomembnih razlik med dečki in deklicami. Zanimivo bi bilo na istem vzorcu učencev ugotoviti, ali se razlike med spoloma pojavijo npr. ob koncu prvega ali drugega vzgojno-izobraževalnega obdobja, saj nekatere raziskave kažejo na to, da se razlike med dečki in deklicami pojavijo kasneje, niso pa zaznane na začetku šolanja.

Na podlagi izvedene raziskave in prebrane literature lahko zaključimo, da kronološka starost otrok ali njihov spol ne vpliva na uspešnost pri matematiki $v$ prvem razredu. Veliko pomembnejši dejavniki učenčeve uspešnosti so izobrazbena struktura staršev ter socialno-ekonomski položaj družine in delno tudi vključenost $v$ vrtec, ki ima pozitiven učinek predvsem pri otrocih staršev z nižjo izobrazbo.

\section{Literatura}

Bergant, T. 2012. »Nevrokognitivne osnove numeričnega procesiranja.« Psihološka obzorja 21 (3-4): 69-74.

—. 2014a. »Ali malček spoznava matematiko že v vrtcu?« V Spodbujanje matematičnega mišljenja v vrtcu, ur. B. Vrbovšek, M. Domicelj in D. Belak, 12-17. Ljubljana: Supra.

—. 2014b. »Kdaj je otrok zrel za všolanje?« Didakta 24 (117): 28-31.

Burr, T. 2008. Mathematics Performance in Primary Schools: Getting the Best Results. London: National Audit Office.

Cahan, S., in N. Cohen. 1989. »Age versus Schooling Effects on Intelligence Development."Child Development 60 (5): 1239-1249.

Cahan, S., C. Greenbaum, L. Artman, N. Deluya in Y. Gappel-Gilon. 2008. »The Differential Effects of Age and First Grade Schooling on the Development of Infralogical and Logico-Mathematical Concrete Operations." Cognitive Development 23 (2): 258-277.

Cecić Erpič, S. (1999). »Kognitivne sposobnosti otrok ob vstopu v polo.« V Razvojnopsihološke značilnosti različno starih otrok ob vstopu v šolo, ur. M. Zupančič, 20-42. Ljubljana: i2. 
Cross, C. T., in T. A. Woods. 2009. Mathematics Learning in Early Childhood: Paths Toward Excellence and Equity. Washington, DC: The National Academies Press.

Cotič, M., in D. Felda. 2014. »Didaktika zgodnjega učenja matematike.« V Zgodnje učenje matematike: zbornik konference, ur. K. Čuk in R. Tul, 1-10. Trst: Edizioni Università di Trieste.

Felda, D., in M. Cotič. 2012. »Zakaj poučevati matematiko." Revija za elementarno izobraževanje 5 (2-3): 107-120.

Gaber, S., in L. Marjanovič Umekč 2009. Študije (primerjalne) neenakosti. Ljubljana: Pedagoški inštitut.

Haylock, D., in F. Thangata. 2007. Key Concepts in Teaching Primary Mathematics. Los Angeles, London, New Delhi in Singapore: Sage.

Japelj Pavešić, B. 2014. »Predšolsko znanje matematike v luči mednarodnih primerjav.«V Spodbujanje matematičnega mišljenja v vrtcu, ur. B. Vrbovšek, M. Domicelj in D. Belak, 18-30. Ljubljana: Supra.

Kozmelj, A. 2020. »Tudi v šolskem letu 2019/20 osnovnošolcev več, srednješolcev pa nekaj manj kot v preteklih letih. «Statistični urad Republike Slovenije. https://www.stat.si/StatWeb/News/Index/8854.

Kresal Sterniša, B., in T. Plevnik, ur. 2012. Matematično izobraževanje v Evropi: skupni izzivi in nacionalne politike. Ljubljana: Ministrstvo za izobraževanje, znanost, kulturo in šport.

Larsen, S. A., C. W. Little in W. L. Coventry. 2021. »Exploring the Associations Between Delayed School Entry and Achievement in Primary and Secondary School.« Child Development 92 (2): 774-792.

Lipovec, A., in D. Antolin Drešar. 2019. Matematika v predšolskem obdobju. Maribor: Univerzitetna založba Univerze v Mariboru.

Marjanovič Umek, L., U. Fekonja in K. Bajc. 2006. »Dejavniki otrokove pripravljenosti za šolo.« Psihološka obzorja 15 (2), 31-51.

Ministrstvo za šolstvo in šport. 1999. Kurikulum za vrtce: predšolska vzgoja v vrtcih. Ljubljana: Ministrstvo za šolstvo in šport in Zavod Republike Slovenije za šolstvo.

- 2011. Učni načrt: program osnovna šola; matematika. Ljubljana: Ministrstvo za šolstvo in šport in Zavod Republike Slovenije za šolstvo.

National Council of Teachers of Mathematics. 2000. Principles and Standards for School Mathematics. Reston, VA: National Council of Teachers of Mathematics.

Oshima, T. C., in C. S. Domaleski. 2006. »Academic Performance Gap Between Summer-Birthday and Fall-Birthday Children in Grades K-8." The Journal of Educational Research 99 (4): 212-217.

»Rethinking School Readiness.« 2008. Policy Brief, št. 10. https://www.rch.org.au/ uploadedFiles/Main/Content/ccch/PB10_SchoolReadiness.pdf.

Sousa, D. A. 2015. How the Brain Learns Mathematics. Thousand Oaks, CA: Sage. 
Stipek, D. J. 2003. »School Entry Age.« https://citeseerx.ist.psu.edu/viewdoc/ download?doi=10.1.1.607.9459\&rep=rep1\&type=pdf.

Šterman Ivančič, K., ur. 2019. PISA 2018: program mednarodne primerjave dosežkov učencev in učenk: nacionalno poročilo s primeri nalog iz branja. Ljubljana: Pedagoški inštitut.

Vlahović-Štetić, V., in V. Vizek Vidović. 1998. Kladim se da možeš ... psihološki aspekti početnog poučavanja matematike: priručnik za učitelje. Zagreb: Udruga roditelja Korak po korak.

Zakon o osnovni šoli (ZOsn-UPB3). 2006. Uradni list Republike Slovenije, št. 81. https://www.uradni-list.si/1/objava.jsp?sop=2006-01-3535.

Zupančič, M., in M. Puklek. 1999. »Napoved učne uspešnosti učencev v prvem razredu osnovne šole.« V Razvojnopsihološke značilnosti različno starih otrok ob vstopu v šolo, ur. M. Zupančič, 76-92. Ljubljana: i2.

Žakelj, A. 2013. »Novosti in posodobitve učnega načrta za matematiko. « V Posodobitve pouka v osnovnošolski praksi, ur. M. Suban in S. Kmetič, 17-30. Ljubljana: Zavod Republike Slovenije za šolstvo.

\section{Age of Children Entering School and Learning Achievements in Mathematics in the 1st Grade}

As in most European countries, children enter school at the age of six in Slovenia. However, parents have the opportunity to apply for a postponement of schooling for a single school year. In recent years, we have been recording an increasing percentage of delayed enrolment in the 1st grade because of the belief that older students will be able to follow classes more easily and thus be more successful in their studies. In the paper, we focused on success in solving the mathematical test of knowledge according to the different ages of children in the 1st grade. At the same time, we checked whether there are differences in success between boys and girls. Students do not encounter mathematics for the first time upon entering school because they have gradually built mathematical thinking from birth onwards. Early learning of mathematics in the preschool period also has a significant impact on success in mathematics: it lays a solid foundation for upgrading knowledge in further education. Based on our research, we ascertained that both older and younger 1st graders were very equal in knowledge in the mathematical test. Also, no difference in knowledge emerged between boys and girls.

Keywords: learning success in mathematics, age, gender 